\title{
GRĖSMĖS VALSTYBE்S SAUGUMUI: APELIACINIŲ RŪMŲ PRAKTIKA
}

\author{
Tadas Valančius \\ Mykolo Romerio universiteto Viešosios teisès instituto doktorantas
}

\begin{abstract}
Anotacija. Mokslo darbas skirtas apžvelgti 1918-1940 m. jauniausios nacionalinès teismu sistemos grandies - Apeliaciniu Rümu - veikla ir atskleisti iki šiol teisès ir istorijos doktrinai neatrastus baudžiamujų bylu dèl grèsmiu valstybès tyrimo saugumui bruožus. Tyrimo metu išanalizuotos 326 Apeliaciniu Rūmu jurisprudencijos baudžiamosios bylos, kuriose baudžiamojon atsakomybèn patraukti 245 asmenys, taip pat amžininku ir šiu laiku teisès bei istorijos mokslo doktrinos formuotoju suponuoti šaltiniai, teisès aktai, archyvinè medžiaga. Teismo veikla, nagrinèjant baudžiamąsias bylas dèl grèsmiu valstybès saugumui, vertintina kaip strategiškai reikšminga, tačiau komplikuota dèl nusikalstamu veiku konspiratyvumo, politiniu ir ideologiniu aspektu, sprendimu priemimo motyvu diferenciacijos. Apeliaciniai Rūmai, igyvendindami ìstatymo leidejo deleguota kompetencija, rèmési recepuotaisiais ir nacionaliniais teisès aktais, kuriu nuostatos, nors ir kritikuotos dèl galimu žmogaus teisiu pažeidimu, tačiau vertintinos kaip atspindinčios realias grèsmes valstybès saugumui.
\end{abstract}

Pagrindiniai žodžiai: valstybès saugumas, teismas, jurisprudencija, Apeliaciniai Rümai, tarpukaris.

\section{Ivadas}

Apeliaciniai Rūmai - tai jauniausia Lietuvos Respublikos (1918-1940 m.) teismų sistemos grandis, kuriai, artėjant Antrajam pasauliniam karui, suteikta strategiškai reikšminga funkcija - vieningai tirti nusikalstamas veikas, nukreiptas prieš valstybès saugumą ${ }^{1}$. Paradoksalu, tačiau šis valstybès istorijos segmentas teisès ar istorijos doktrinos formuotojų iki šiol nesudomino. Taigi iki šiol neatskleista, kokie nusikaltimai kèlè grèsmę valstybès saugumui, artèjant tragiškiems 1940 m. birželio 15 d. ịvykiams.

Tyrimo problematika formuluojama, keliant klausimus, kokios teisinès ir politinès aplinkybės formavo Apeliacinių Rūmų kaip pirmosios instancijos teismo praktiką ir kokios grèsmès valstybès saugumui bei jų tendencijos identifikuotinos šio teismo tirtose baudžiamosiose bylose.

1 Teismų santvarkos įstatymas. Vyriausybès žinios. 1933, Nr. 419-2900 
Grèsmių valstybės saugumui išaiškinimas, lankstus jų teisinis reglamentavimas ir sankcionavimas - aktualus probleminis klausimas bet kuriuo valstybės egzistavimo laikotarpiu, todèl Apeliacinių Rūmų praktikos analizè suteikia galimybę ịvertinti istorinę praktiką, identifikuojant ir nagrinëjant nusikalstamas veikas, kèlusias grèsmę valstybès saugumui, jos istorijai reikšmingu laikotarpiu.

Šio darbo objektu laikytina iki šiol mokslininkų dėmesio nesulaukusi unikali teismo praktika 1933-1940 m. laikotarpiu, todèl šio tyrimo tikslas - remiantis unikaliais archyviniais šaltiniais ir moksline literatūra, atlikti Apeliacinių Rūmų kaip pirmosios instancijos teismo veiklos analizę ir atskleisti nusikalstamų veikų prieš valstybès saugumą nagrinèjimo ypatumus.

Tyrime keliamas dualistinis uždavinys: 1) identifikuoti Apeliacinių Rūmų jurisprudencijoje tirtas grèsmes valstybès saugumui ir 2) išskirti pagrindinius teisminès valdžios praktikos bruožus, nagrinèjant šio pobūdžio baudžiamąsias bylas.

Šio uždavinio sprendimui naudojamos mokslinès literatūros analizès, 1918-1940 m. teisès aktų ir archyvinių šaltinių analizès, istorinis lyginamasis, statistinis bei apibendrinimo metodai. Mokslinès literatūros analizès metodas. Remiantis šiuo metodu, siekiama apžvelgti ir įvertinti Lietuvos teisès istorijos doktrinoje minimas Apeliacinių Rūmų raidą formavusias istorines bei teisines aplinkybes. Teisès aktu analizes metodas. Šis metodas naudojamas, nustatant Apeliacinių Rūmų kompetenciją, nagrinėjant baudžiamąsias bylas prieš valstybės saugumą reglamentavusias teisès normas. Archyviniu šaltiniu analizès metodas. Naudojant ši metodą, atliekama Apeliacinių Rūmų kaip pirmosios instancijos teismo praktikos analizè. Istorinis lyginamasis metodas. Šio metodo taikymas suponuoja galimybę ịvertinti Apeliacinių Rūmų veiklos reikšmę 1933-1940 m. nacionalinèje teismų sistemoje. Statistinis metodas. Remiantis šiuo metodu, nustatomas nusikalstamas veikas ịvykdžiusių asmenų, teismo išnagrinètų bylų, pritaikytų bausmių ir grèsmių valstybės saugumui formų statistinis santykis. Apibendrinimo metodas. Šiuo metodu siekiama apibendrinti naudotą literatūrą, ịvertinti tyrimo rezultatus bei pateikti išvadas.

\section{Grèsmių valstybès saugumui nagrinėjimas 1918-1933 m. teismų sistemoje}

Pirmaisiais atkurto valstybingumo metais nacionalinès teisingumo sistemos kūrèjų akiratyje nestigo radikalių iššūkių. Iš Rytų stiprèjo komunistinės ideologijos ekspansija, Pietuose grasè teritorinių ambicijų neslepianti Lenkija, o pats nepriklausomybès atkūrimas faktiškai vyko vokiečių okupacijos sąlygomis. Sudètingu politinių, ekonominių bei socialinių aplinkybių ir jų padarinių sąveika neabejotinai nuolat kèlè grèsmę nacionaliniam saugumui.

Pirmasis valstybės Ministras Pirmininkas Augustinas Voldemaras $1919 \mathrm{~m}$. tiesioginių grèsmių valstybès saugumui neįžvalgè ir oficialiai laikèsi nuosaikios pozicijos: „, $<>>$ karo mes su niekuo nevedame ir nei vienas iš mūsų kaimynų vokiečių, lenkų, ukrainų, rusų ir latvių - neturi pamato ant mūsų užpuldinèti. Taigi 
didelių spėkų rubežiams sergèti ir nereikalinga, kad valstybėn neisibrautų vogčia tas, kas neturi teisès mūsų kraštan atvykti“ ${ }^{\text {} 2}$. Vyriausybès vadovui lyg antrindamas įstatymų leidejjas iki $1919 \mathrm{~m}$. nereglamentavo grèsmių valstybès saugumui, nors amžininkai dèl šio poreikio buvo kategoriški ${ }^{3}$.

Nepaisant atitinkamų politinių sluoksnių skeptiško nuosaikumo, 1919 m. paskelbti Ypatingi valstybės apsaugos įstatai ${ }^{4}$ (toliau - YVAĮ), kurie pirmąkart nacionalinèje teisès sistemoje numatė atsakomybę už veikimą prieš valstybės interesus ir lakoniškai pateikẻ šių veikų sąrašą: ,ginkluotas sukilimas“, „priešingas valstybei kariuomenès kurstymas“, „susisiekimo priemonių gadinimas“, „karinių medžiagų naikinimas“, „ginklų slëpimas ir nešiojimas“, „šnipinèjimas“, „priešvalstybinė agitacija“ (14 str.). İstatymų leidejjas pabrèžè šių nusikalstamų veikų pavojingumą, nurodydamas, kad ịvykdžiusieji jas ,gali būti svarbiais atsitikimais baudžiami mirties bausme“. YVAİ išsamiau šių nusikaltimų nereglamentavo, pateikiant nuorodas tik i jų sudètis numačiusị 1903 m. Rusijos Baudžiamaji kodeksą ${ }^{5}$, vèliau pervadintą Baudžiamuoju statutu (toliau - B. St., aut.) - toks pavadinimas figūravo iki pat 1940 metų.

Grèsmių valstybès saugumui nagrinėjimas iš pradžių deleguotas apygardos teismams, tačiau jau netrukus ši kompetencija perduota naujai ịsteigtiems karo teismams ${ }^{6}$. Pastarieji teismai nagrinejo išskirtinai tik baudžiamąsias bylas, o jų ịvaizdis visuomeneje buvo autoritetingas. Viena to priežasčiu - aukščiausios bausmès: jurisdikcija skirti mirties bausmę. ${ }^{7}$ Aptariami teismai nagrinejjo ne tik aktyvios ir pasyvios karinès tarnybos atstovų - karininkų, kareivių, karo valdininkų ir Krašto apsaugos ministerijos civilių tarnautojų, karo belaisvių, šaulių - bylas, tačiau taip pat tyrè ir civilių galimai įvykdytas nusikalstamas veikas, kurių turinys buvo susijęs su bendraisiais nusikaltimais ir nusikaltimais karo tarnybai. ${ }^{8}$ Karo lauko teismas nagrinejjo tiek kariškių, tiek civilių asmenų bylas dèl šnipinèjimo, antivalstybinès agitacijos kariuomenejje, karo veiksmų arba karo padèties vietovėse, taip pat okupuotoje arba svetimose valstybėse sukurtų organizacijų dalyvių ir jų padejjejjų bylas dèl kariškių drausminių nusikaltimų ir kt. Kariuomenès teismas, nesant karo padèties, nagrinejjo kariškių ir „asmenų, priklausančių kariuomenei“, karininkų, kareivių, Krašto apsaugos ministerijos civilių tarnautojų, šaulių (už tarnybinius nusikaltimus) bylas, kurios nepriklausė pulko teismui. Pulko teismas nagrinejjo kareivių, Krašto apsaugos ministerijos ir civilių tarnautojų, šaulių (tik už tarnybinius nusikaltimus) bylas, kai galèjo būti skiriama su laisvès atėmimu nesusijusi bausmė arba civilinis ieškinys baudžiamojoje byloje neviršijo 2000 Lt, jeigu pavogtų ar išeikvotų daiktų vertè - 200 Lt. $^{9}$

2 Skipitis, R. Nepriklausoma Lietuva: atsiminimai, Čikaga: 1967, p. 71.

3 Byla, J. Teismas nusik. darbų prieš Valstybès saugumą. Teisé, 1935, Nr. 29, p. 61.

4 Ypatingi valstybès apsaugos įstatai. Laikinosios Vyriausybès žinios. 1919, Nr. 5/3.

5 Baudžiamasis kodeksas. Laikinosios Vyriausybès žinios. 1919, Nr. 2-3/26; sud. Jablonskis, K. Baudžiamasis statutas, sud. Kaunas: 1930.

6 Karo teismo įstatai, Laikinosios Vyriausybès žinios, Kaunas 1919, Nr. 6/62.

7 Stoliarovas, A. Lietuvos Respublikos kariniai teismai 1919-1940 m. Daktaro disertacija. Kaunas: Vytauto Didžiojo universitetas, 2012, p. 117.

8 Ibid, p. 123.

9 Dvareckas, S. Lietuvos teismai 1918-1940 m., Vilnius, 1997 m., p. 36. 
Taigi iš esmès pirmaisiais nepriklausomybès metais, veikiant „laikinajai“ nacionalinei teismų sistemai, grèsmių valstybès saugumui nagrinèjimas nebuvo patikimas bendrosios kompetencijos teismams. Baudžiamųjų bylų dèl šių nusikalstamų veikų nagrinejjimo monopolis buvo patikètas karo teismams, turejjusiems itin plačius igaliojimus veikti karo stovio sąlygomis. Karo stovis, paskelbtas 1919 m. vasario 7 d., aptariamuoju laikotarpiu buvo atšauktas vos keletą kartų: $1920 \mathrm{~m}$. kovo-liepos mėnesiais ir $1926 \mathrm{~m}$. antraji pusmeti - tad karo teismų kompetencija iš esmès nesusiaurèdavo. Greičiausiai, visa tai lėmè, kad grèsmès valstybès saugumui oficialiuose teisès aktuose detaliau nereglamentuotos.

Tačiau tai, kad šių nusikalstamų veikų reglamentavimas išliko problemine sritimi, akivaizdu iš įdirbio, atlikto ruošiant 1933 m. teismų reformą, kuriai reformos architektų darbotvarkèje skirtas reikšmingas dėmesys ${ }^{10}$.

\section{Apeliaciniai Rūmai Lietuvos Respublikos teismų sistemoje}

1918 m. vasario 16 dieną, atkūrus valstybingumą ir siekiant apginti ir išsaugoti deklaruotas vertybes bei suverenitetą, skubiai formuota teisine įstatyminè bazè. Iki Pirmojo pasaulinio karo Lietuvos teritorijoje veikusi teismų sistema, kurią reglamentavo $1864 \mathrm{~m}$. Rusijos teismų santvarkos įstatymas, nelaikyta tinkama ${ }^{11}$, todèl skubiai formuota pirmoji autonomiška Lietuvos Respublikos teismų sistema. Jos pradžia laikytinas pirmojo Lietuvos teisingumo ministro Petro Leono $1918 \mathrm{~m}$. gruodžio 14 dieną pasirašytas įsakymas ${ }^{12}$, kuriuo pradètas ịgyvendinti teismų sandarą ir veiklą reglamentavęs teisès aktas - Laikinasis Lietuvos teismų ir jų darbo sutvarkymo įstatymas ${ }^{13}$.

Lakoniškas skubiai rengtas vos 36 straipsnių apimties teisès aktas buvo gyvybiškai reikalingas besisteigiančiai Lietuvos teisinei sistemai, ypač eliminuojant tuomet dar gajus okupacinès valdžios hegemonijos pėdsakus. Juo numatyta pirmoji trinare nacionaline teismų sistema, sudaryta iš Vyriausiojo Tribunolo, apygardų teismų ir taikos teisejjų ( 3 str.). Nors įstatymo pavadinime įrašytas terminas „laikinasis“ reiškè „oficialų valdžios ịsipareigojimą neilgai trukus jị keisti“"14, tačiau ši primityvi nacionalinès teismų sistemos konstrukcija buvo pakankamai gyvybinga ir įstatymų

\footnotetext{
10 Tokią išvadą pagrindžia archyviniuose fonduose išlikę įstatymų projektai, skirti nacionalinei teismų reformai (LCVA f. 923, ap. 1, b. 784, 1. 11) ir grèsmių valstybės saugumui detaliam reglamentavimui ([be datos] Valstybei apsaugoti įstatymo projektas. LCVA F. 923, ap. 1, b. 790, 1. 322). Nors įstatymų leidžiamosios valdžios jie nebuvo patvirtinti, tačiau atspindi dėmesi aptariamajai problematikai. Pirmasis Teismų santvarkos ịstatymo projektas numate „,baudžiamųjų bylų, padarytų prieš valstybès saugumo ịstatymus" nagrinèjimą naujai steigiamam teismui - Apeliaciniams Rūmams. Tik, nesant tokių teisès aktų definicijos, šios formuluotès buvo atsisakyta.

11 Maksimaitis, M. Teismų santvarkos pagrindų formavimasis Lietuvoje (1918-1933). Jurisprudencija. 2013, 20 (2), p. 377.

12 Laikinosios vyriausybès ịsakymai. Lietuvos aidas. 1918, 158 (206), p. 1.

13 Laikinasis Lietuvos teismų ir jų darbo sutvarkymas. Laikinosios Vyriausybès žinios. 1919, Nr. 2-3/26.

14 Supra note 11, p. 377.
} 
leidejjas „laikinojo“ ịstatymo nepakeite 15 pirmųjų nepriklausomos valstybės metų. $1928 \mathrm{~m}$. ịsteigta Valstybès Taryba tapo lemiamu veiksniu, modernizuojant Lietuvos Respublikos teismų sistemą. Jei iki jos ịsteigimo teismų reformos bandymai strigdavo Teisingumo ministerijos koridoriuose ${ }^{15}$, Valstybès Tarybai vos per keletą metų pavyko įstatymo projektu įtvirtinti naują nacionalinès teismų sistemos koncepciją ir i ją integruoti visiškai naują teisminę instituciją - Apeliacinius Rūmus $^{16}$. Oficialiai teismų sistemos reforma igyvendinta ir naujasis Teismų santvarkos i̊statymas ${ }^{17}$ buvo paskelbtas $1933 \mathrm{~m}$. liepos 11 dieną. Tai buvo kur kas išsamesnis už savo pirmtaką 488 straipsnių ịstatymo projektas, kuris suponavo naują keturnarę teismų sistemą: žemiausia grandimi numatyti apylinkès teismai, antraja - apygardos teismai, ties trečiaja naujosios santvarkos pakopa atsidūrè Apeliaciniai Rūmai, o Vyriausiasis Tribunolas išliko aukščiausia grandimi valstybės teismų sistemoje.

Abi aptariamuoju laikotarpiu (1928 m. ${ }^{18}$ ir $\left.1938 \mathrm{~m} .{ }^{19}\right)$ veikusios Konstitucijos teismo instituciją pozicionavo kaip vieną iš valstybès valdžios vykdymo institutų, o Teismų santvarkos ịstatymas moderniojoje teisès doktrinoje apibūdinamas tobulu tiek savo turiniu, tiek forma ${ }^{20}$. Jis nustate atsakingą siekị ịkurti visiškai naują precedento valstybejje neturintį teismą ir pavesti jam įgyvendinti dvi strateginès reikšmès funkcijas, turinčias ir nacionalinio saugumo potekstę.

İstatymų leidèjas Apeliaciniams Rūmams iš esmès numatė trejopą kompetenciją:

1. Kaip apeliacinę instanciją byloms, kurias sprendžia apygardų teismai, pirmaja instancija (18 str.) - tirti apeliacine tvarka apskųstus apygardos teismų sprendimus, už kuriuos nustatyta sunkiujų darbų kalejjimo bausmè. Šios bylos sudare didžiają dalį Apeliaciniuose Rūmuose nagrinètų bylų $-5403^{21}$.

2. Kaip pirmają instanciją baudžiamosioms byloms dèl nusikalstamų darbų, padarytų valstybės teritorijoje arba užsienyje prieš valstybès saugumą (19 str.). Tokių bylų išspręsta $340^{22}$.

15 Maksimaitis, M. Iš Lietuvos teismų istorijos: Apeliaciniai Rūmai (1933-1944), Jurisprudencija. 2014, 21 (1), p. 29.

16 Pirmasis šio įstatymo projektas Apeliacinių Rūmų funkcijas reglamentavo pakankamai lakoniškai, numatydamas jam trinarę kompetenciją (16-18 str.), iš esmès nesiskyrusią nuo patvirtinto įstatymo projekto, tačiau čia Apeliaciniams Rūmams numatyta pirmąja instancija nagrinèti „baudžiamąsias bylas, padarytas prieš valstybès saugumo įstatymus“ (17 str.). Darytina prielaida, kad, nesant tokių teisès aktų definicijos, šios formuluotès buvo atsisakyta. 1932-12-31 Valstybès tarybos rengiamas Teismų santvarkos įstatymo projektas. $L C V A$ f. 923, ap. 1, b. 784, 1. 11.

17 Supra note 1.

18 Lietuvos Valstybės Konstitucija. Vyriausybès žinios. 1928, Nr. 275/1778.

19 Lietuvos Konstitucija. Vyriausybès žinios. 1938, Nr. 600-4199.

20 Vilbikas, A. Teismai ir teiséjai Lietuvoje (1918-2008). Šiauliai, 2009, p. 66.

21 Supra note 15, p. 33.

22 M. Maksimaičio pateikiami duomenys neatitinka faktiškai Apeliaciniuose Rūmuose išnagrinètų baudžiamujjų bylų kiekybinès išraiškos. LCVA f. 932 ap. 1 ir 2 saugomos 326 baudžiamosios bylos. Toks neatitikimas, tikètina, galèjo ịvykti dèl jų apskaitos ir archyvavimo aspektų: kai kurios bylos dubliuojamos, dingusios arba išskirtos ị atskirus vienetus. Supra note 15. 
3. Kaip pirmają instanciją byloms, kurias teismui paveda kiti ịstatymai (20 str.). Faktiškai Apeliaciniai Rūmai taip pat nagrinèjo skundus dèl prokuroru nutarimų nutraukti parengtinį tardymą arba kvotą; skundus dẻl apygardos teismų nutarimų ir prokurorų išvadų nutraukti kaltinamaji persekiojimą ir kt. ${ }^{23}$ Iš viso 1933-1940 m. laikotarpiu tokio tipo bylų būta 4446.

Visapusiškas teismo funkcionavimas prasidejo jau 1933 m. pabaigoje, o pirmaja instancija nagrinètina pirmoji baudžiamoji byla teismą pasiekè $1934 \mathrm{~m}$. birželio $21 \mathrm{~d} .{ }^{24}$ Tačiau sąlyginai produktyvus teismų darbo ciklas tęsèsi pakankamai trumpai. Tragiškas pasekmes Lietuvos valstybingumui turèję 1940 metų birželio ịvykiai neaplenkè ir Apeliacinių Rūmų. Sovietams okupavus Lietuvą, tarpukario Lietuvos teisès patirtis buvo atmesta ${ }^{25}$. Pagal $1940 \mathrm{~m}$. rugpjūčio 3 dieną SSRS Aukščiausiosios Tarybos priimtą ịstatymą Lietuvos teritorijoje ėmè veikti SSRS konstitucija. 1940 m. rugpjūčio 25 d. Lietuvos TSR Aukščiausioji taryba išrinko visiškai naujos sudèties Lietuvos TSR Aukščiausiajj teismą ir taip panaikino Vyriausiajį Tribunolą bei Apeliacinius Rūmus ${ }^{26}$. Nors Apeliacinių Rūmų veiklą atkurti bandyta vokiečių okupacijos metais, visgi esminè jo funkcija - vykdyti teisingumą - laikytina iškreipta okupantų primestų teisès aktų ir karo padèties.

Nors jauniausia nacionalinès teismų sistemos grandis nepriklausomai nuo geopolitinių pokyčių veikẻ tik trečdali viso valstybingumo laikmečio, tačiau nuosekli ir integrali šio teismo veikla, tikètina, pateisino įstatymų kūrejjo lūkesčius. Šią prielaidą tik sustiprina $1995 \mathrm{~m}$. sausio 1 d. įsteigtas Lietuvos apeliacinis teismas, kuris atspindi moderniosios teismų sistemos kūrèjų siekį užtikrinti nacionalinès teismų sistemos tęstinumą ir laikytinas Apeliacinių Rūmų atkūrimu ${ }^{27}$.

\section{Grèsmiụ valstybès saugumui nagrinėjimo Apeliaciniuose Rūmuose ypatumai}

Teismų santvarkos įstatymu Apeliaciniams Rūmams numačius kompetenciją pirmaja instancija spręsti , <...> nusikalstamujų darbų, padarytų valstybės teritorijoje arba užsienyje prieš valstybès saugumą“, ši „darbų“" sąvoka netruko sukelti teisini disputą $^{28}$. Teismas kvestionavo abstrakčiai ir lakoniškai reglamentuotas nusikalsta-

23 Supra note 9, p. 34.

24 1934-06-21 LR Biržų raj. Apygardos teismo tardytojo galutinis nutarimas dèl bylos perdavimo Apeliacinių Rūmų prokurorui. LCVA f. 932 ap. 1, b. 310, 1. 117.

25 Sagatienè, D. Sovietiniai bendrosios kompetencijos teismai Lietuvoje 1940-1941 ir 1944-1953 metais. Daktaro disertacija. Socialiniai mokslai, teisè. Vilnius: Mykolo Romerio universitetas, 2013, p. 21.

26 LTSR Liaudies Komisarų Tarybos 1940 m. rugsèjo 26 d. nutarimas Nr. 162 „Dèl Vyriausiojo Tribunolo ir Apeliacinių Rūmų panaikinimo“. LTSR Aukščiausiosios Tarybos žinios. 1940, Nr. 3-53.

27 Apeliacinès instancijos ịkūrimas. Lietuvos apeliacinio teismo tinklalapis: http://www. apeliacinis.lt/lt/veikla/teismo-istorija/apeliacines-instancijos-ikurimas.html [Žiūrèta 2015-08-24].

28 Römeris, M. Konstitucinès ir teismo teisès pasieniuose. Kaunas: Vytauto Didžiojo universiteto Teisių fakultetas, 1931, p. 62. 
mas veikas. Laikinai ginčas išspręstas 1933 m. lapkritị pateiktu Vyriausiojo Tribunolo išaiškinimu, nurodžiusiu, kad nusikalstamų veikų sudėtys reglamentuotos Baudžiamojo Statuto IV ir V skyriuose „Apie valstybès išdavimą“, „Sąmyšį““ ir kituose atskiruose jo straipsniuose, leidžiančiuose „padaryti visai aiškias išvadas“ dẻl grèsmių ir jų sąvokų ${ }^{29}$.

Tačiau, tęsiantis neapibrèžtumui dèl šio tipo bylų priklausomybès, 1934 m. vasario $8 \mathrm{~d}$. priimtas Tautai ir valstybei saugoti įstatymas ${ }^{30}$ (TVSİ), išsamiai reglamentavęs nusikalstamų veikų prieš valstybės saugumą sudètis ir sankcijas. Juo nustatyta, kad Apeliaciniai Rūmai valstybėje tapo vienintele instancija, turinčia kompetenciją nagrinèti tokio pobūdžio baudžiamąsias bylas. Vèliau tai patvirtino Vyriausiasis Tribunolas, pažymėjęs, kad YVAI 14 str. numato tik ypatingai valstybei svarbioms byloms ir tik karo metu priklausomybę Kariuomenès Teismui, o visais kitais atvejais bylos prieš valstybès saugumą turi būti sprendžiamos Apeliaciniuose Rūmuose ${ }^{31}$.

Patys Apeliaciniai Rūmai darbą vykdydavo trejopo tipo posèdžiuose (30 str.):

1. Teisiamuosiuose - trijų teisèjų kolegija sprendè teismo jurisdikcijai priklausančias baudžiamąsias bylas pirmaja instancija. Šie posėdžiai buvo vieši (52 str.).

2. Tvarkomuosiuose - trijų teisèjų kolegija sprendè bylų klausimus, kurie ìstatymais gali arba turi būti sprendžiami tokiuose posèdžiuose. Šie teismo posèdžiai nebuvo vieši (52 str.).

3. Visuotiniuose susirinkimų posėdžiuose - spręsti klausimai, kuriuos teismui pavede įstatymas. Juose privalèjo dalyvauti bent $2 / 3$ teisèjų ( 48 str.). Šie posèdžiai buvo ne vieši (52 str.).

Priimti sprendimai buvo skelbiami Lietuvos Respublikos vardu (53 str.). Posẻdžių kalba buvo lietuvių kalba (61 str.), tačiau nemokantieji lietuvių kalbos turèjo teisę ị vertėją (62 str.).

Nagrinejjant baudžiamąsias bylas dèl grèsmių prieš valstybės saugumą, vadovautasi Baudžiamojo proceso ịstatymu ${ }^{32}$, Teismų santvarkos įstatymo bei TVSI nuostatomis. Ikiteisminis tyrimas prasidedavo kvota (1035 str.), kurią kontroliavo ir vykdè išimtinai saugumo struktūrų pareigūnai - Valstybès saugumo departamento arba Valstybès saugumo policijos valdininkai. Jie turejjo galimybę atlikti apžiūrèjimus, patikrinimus, kratas, poèmius, vykdyti apklausas, peržiūrèti ar paimti pašto arba telegrafo korespondenciją ( $1035^{11}$ str.). Užbaigta kvota buvo perduodama Apygardos teismo prokurorui $\left(1035^{23}\right)$, kuris su Apeliacinių Rūmų prokuroro pritarimu imdavosi kuruoti reikiamus rengiamojo tardymo veiksmus $\left(1035^{28}\right.$ str.). Rengiamaji tardymą atlikdavo atitinkamo Apygardos Teismo tardytojas, o pats tardymas negalejjo būti pradètas be pakankamo pagrindo (262 str.). Tokiose bylose „pakankamas“

29 Sud. Byla, J. Vyriausiojo Tribunolo 1924-1933 metu visuotiniu susirinkimu nutarimu rinkinys su Teisingumo ministerijos aplinkraščiais ir dalykine rodykle. Kaunas: Karvelio ir Rinkevičiaus prekybos namų leidinys. 1934, p. 309.

30 Tautai ir valstybei saugoti įstatymas. Vyriausybès žinios. 1934, Nr. 437-3044.

31 Supra note 15.

32 Kavolis, M. Baudžiamojo proceso įstatymas su komentarais. Kaunas: „Literatūros“ knygynas. $1933 \mathrm{~m}$. 
pagrindas buvo preziumuojamas, ypač dažnai remiantis vien slaptomis „agentūrinèmis“ žiniomis. Užbaigus rengiamajị tardymą, byla buvo siunčiama Apeliacinių Rūmų prokurorui, kuris surašydavo kaltinamajji aktą arba pateikdavo išvadą apie tardymo nutraukimą (1039 str.).

Kaltinamajame akte prokuroras kvalifikuodavo nusikalstamą veiką pagal atitinkamą baudžiamosios teisès normą ir pateikdavo kaltinamajj pagrindą. İvykdžius ikiteisminius procesinius veiksmus, baudžiamoji byla buvo sprendžiama viešame arba uždarame posėdyje. Tiesa, uždarame posėdyje Apeliaciniai Rūmai nagrinejjo tik pirmojo Lietuvos Ministro Pirmininko Augustino Voldemaro baudžiamają bylą ${ }^{33}$, kèlusią visuomenèje ažiotažą ${ }^{34}$. Baudžiamąsias bylas teisejjai sprende remdamiesi savo vidaus įsitikinimu, pagrịstu visomis išžiūretomis aplinkybemis (766 str.). Pakankamai dažnai teismas vertindavo ir ekspertų išvadą, pvz., ypač dažnai buvo pasitelkiami rašysenos ${ }^{35}$ ekspertai, tačiau jų išvados nebuvo privalomos ${ }^{36}$.

Teismas galëjo priimti trejopą sprendimą (771 str.): 1) kaltinamąji išteisinti, kai kaltinimas nėra ịrodytas; 2) kaltinamaji atleisti nuo bausmès, remiantis teisèta priežastimi; 3) kaltinamajji nubausti, jei šis pripažįstamas padaręs nusikalstamaji darbą. Drauge teismas spręsdavo ir kitas nusikalstamojo darbo pasekmes (776 str.): 1) dèl daiktinių ịrodymų; 2) nuostolių atlyginimo; 3) teismo išlaidų padengimo. Ir tik tada buvo surašoma sprendimo rezoliucija, kurią pasirašydavo visi teisèjai (786 str.), o su sprendimu buvo supažindinamos bylos šalys.

Apeliacinių Rūmų pirmaja instancija priimti sprendimai apeliacine tvarka nebuvo skundžiami. Visi teismo sprendimai buvo galutiniai (Baudžiamojo proceso ịstatymo 854 str.) ir apskundžiami galèjo būti tik kasacine tvarka, teikiant kasacini skundą arba protestą (Baudžiamojo proceso įstatymo 1058 str.) Vyriausiajam Tribunolui. Iš viso 1934-1940 m. laikotarpiu dèl Apeliaciniuose Rūmuose pirmaja instancija priimtų sprendimų kasacijos skundai buvo pareikšti 88 baudžiamosiose bylose.

Apskritai baudžiamosios bylos Apeliaciniuose Rūmuose nagrinètos gan operatyviai. Daugumą bylų išsprende per trumpesni nei 6 mẻnesių laikotarpi ir tik nedidele jų dalis teisme nagrinètos nuo 6 mènesių iki 1 metų arba ilgiau. Nẻ viena baudžiamoji byla teisme nenagrinèta ilgiau 3 metų. Teisès doktrinoje atkreipiamas dẻmesys ir į nepriekaištingą bylų vedimo tvarką ${ }^{37}$.

\footnotetext{
33 1934-11-08 Teisingumo ministro prašymas Apeliacinių Rūmų pirmininkui. LCVA f. 932, ap. 1, b. $52,1.142$.

34 Prof. Voldemaras nubaustas, o Karutis išteisintas. Diena. 1934, 45.

35 1939-11-18 Apeliacinių Rūmų sprendimas Jono Vyšniausko, Boleslovo Jankausko, Jono Račio baudžiamojoje byloje. LCVA f. 932, ap. 1, b. 318, 1. 180; 1936-09-17 LR Apeliacinių Rūmų sprendimas Gintauto Juozo baudžiamojoje byloje. $L C V A$ f. 932 , ap. 1, b. 62, 1. 36.

36 [Be datos] Teisingumo ministerijos susirašinèjimas dèl Baudžiamojo kodekso. LCVA 385, ap. 2, b. 296, 1. 2.

37 Supra note 20, 1. 61.
} 


\section{Grèsmių valstybės saugumui teisinis reglamentavimas 1933-1940 m.}

Nagrinèdamas baudžiamąsias bylas dèl grèsmių valstybès saugumui, teismas vadovavosi šio pobūdžio nusikalstamas veikas reglamentavusiais baudžiamaisiais istatymais.

Svarbiausiu jų šiuo laikotarpiu laikytinas recepuotasis Baudžiamasis statutas. Pagal jị iškelta daugiausia baudžiamujjų bylų - net $260^{38}$. Nors šis teisès aktas pripažintas kaip turintis ,sveikų ir išmintingų nuostatų“39, per visą nepriklausomybės laikotarpi B. St. keistas $31 \mathrm{kartą}^{40}$ arba daugiausiai iš visų recepuotujų teisès aktų. Itin reikšmingas buvo Baudžiamojo statuto papildymo ir pakeitimo (B. St. pap. ir pak.) įstatymo $\mathrm{o}^{41}$ prièmimas, kuris įtvirtino tokias nusikaltimų sudètis kaip „ginkluotas sukilimas“ (1 str.), „priklausymas prie slaptų organizaciju“ (6 str.), „valstybės apsigynimo pajègų mažinimas“ (8 str.), „plëšimas ir grobimas“(11 str.) ir kt. Taip pat teismo praktikoje aptinkamos B. St. nuostatos, skirtos valstybės išdavimui (IV skyrius, 109-119 str.), sąmyšio rengimui ir kèlimui (V skyrius, 120-137 str.), valdžios neklausymui (VI skyrius, 138-155 str.). B. St. numate keturnarę sankcijų sistemą: už ịvykdytus nusikaltimus prieš valstybès saugumą galëjo būti skirta sunkiujų darbų kalèjimo, paprastojo kalëjimo bausmè, areštas ir piniginè bauda. Šio teisès akto nuostatos taikytos nusikaltimus valstybės teritorijoje arba užsienyje ịvykdžiusiems Lietuvos piliečiams ir užsieniečiams, nusikaltusiems Lietuvoje (4 str.).

Antrasis pagal reikšmę baudžiamosios teisès aktas - jau minètas TVSİ. Tai išsamus 38 straipsnių sudèties įstatymas. Šiuolaikinèje teisès doktrinoje laikomasi nuomonès, kad aptariamasis teisès aktas iš esmès numate nemaža įvairių, kartais gerokai apibendrintai, nekonkrečiai suformuluotų nusikaltimų sudèčių, tokių kaip lietuvių tautos, Lietuvos valstybès, jos ženklo, vèliavos ir t. t. įžeidimas ar niekinimas (2 str.), piliečių valstybinès ištikimybès, vieningumo ar atsparumo silpninimas (3 str.), pramanytų ar iškraipytų žinių apie valstybės valdžios institucijos ar valstybės įstaigos veikimą skleidimas (16 str.), taip pat paramos nusikalstamam veikimui prieš Lietuvos valstybę užsienyje ieškojimas (4 str.), priklausymas nesuderinamoms su Lietuvos valstybès ar lietuvių tautos interesu užsienio organizacijoms (7 str.), maišto ar kitokio pavojingo valstybei nerimo kẻlimas (14 str.), agitavimas daryti tai, kas kenkia Lietuvos valstybès ar lietuvių tautos interesui (15 str.) ir kt. ${ }^{42}$ Sovietinèje teisès doktrinoje jis buvo linksniuojamas kaip „fašistinis“433.

\footnotetext{
38 Šis skaičius vertintinas kaip atspindintis ir vien pagal B. St. normas, ir pagal sudetines - B. St. ir TVSI - nuostatas iškeltą baudžiamujjų bylų skaičių. İ skaičių neįtrauktos tokios vienu iš baudžiamụjų bylų pagrindo sudètị sudariusios nuostatos kaip B. St. 51 str. (bendrininkavimas), TVSI 26, 27 ir 28 str. nuostatos.

39 Supra note 36.

40 Maksimaitis, M. Rusijos teisés šaltiniai Lietuvoje 1918-1940 m. Jurisprudencija 2012, Nr. 19(2), p. 413.

41 Baudžiamojo statuto papildymas ir pakeitimas. Laikinosios Vyriausybès žinios. 1920. Nr. 20-243.

42 Supra note 15, p. 34.

43 Apanavičius, M., Dvareckas, S. Teismas ir teisingumas Lietuvos TSR. Vilnius: Mintis, 1984, p. 184
} 
Tačiau sutinkama, kad politizuotas ir fundamentalias žmogaus teises, kaip žodžio ar sąžinès laisvè, paminantis teisès aktas nors ir pasižymèjo abstraktumu, jo reikšmè negali būti paneigta vien teisès normų konstrukcijos netobulumu. Apeliaciniai Rūmai iš viso išnagrinèjo beveik pusantro šimto baudžiamujjų bylų, iškeltų šio teisès akto pagrindu (164). Daugiau nei pusejje visų šių bylų buvo priimti apkaltinamieji nuosprendžiai, o jų pagrịstumas ir teismo veikla - sankcionuojant šio pobūdžio nusikalstamas veikas, aptariamas tolesnèse šio tiriamojo darbo dalyse.

\section{Baudžiamosios bylos dèl grèsmių valstybės saugumui Apeliaciniuose Rūmuose}

Iki šiol Lietuvos centriniame valstybès archyve (LCVA) išlikusios 326 baudžiamosios bylos, pirmaja instancija nagrinètos Apeliaciniuose Rūmuose ${ }^{44}$. Nepaisant strateginès reikšmès, iki šiol mokslininkų ir archyvų tyrinètojų dėmesio Apeliacinių Rūmų jurisprudencija nebuvo sulaukusi. Šiuose archyviniuose fonduose saugomos baudžiamosios bylos - vienintelis objektyvus šaltinis, atskleidžiantis teismo tirtas grèsmes valstybės saugumui, jų tipus, kaltinamųų tautinę priklausomybę ir intencijas. Šios bylos gali būti skirstomos ị dešimtị kategorijų pagal grèsmių valstybès saugumui tipus:

1. Priklausymas priešvalstybinę veiklą ịgyvendinančioms slaptoms organizacijoms, veikiant jų naudai.

2. Disponavimas priešvalstybinio turinio literatūra.

3. Lietuvos valstybės ženklo - Vyties, Lietuvos tautinès, valstybinès ar karinès vèliavos arba kito dalyko, turinčio simbolinę reikšmę lietuvių tautai ar valstybei - įžeidimas ar niekinimas.

4. Maišto ar kito pavojingo valstybei nerimo kèlimas.

5. Lietuvos valstybès ar lietuvių tautos įžeidimas ar niekinimas.

6. Priešingas Lietuvos valstybès ar lietuvių tautos interesams veikimas.

7. Lietuvos piliečių valstybinès ištikimybès slopinimas.

8. Kurstymas.

9. Disponavimas padirbtais dokumentais.

10. Kitos nusikalstamos veikos. ${ }^{45}$

Apeliaciniuose Rūmuose teisti 529 asmenys, apkaltinamieji nuosprendžiai perskaityti 245 asmenims. Tiesa, baudžiamojon atsakomybèn patrauktų asmenų skaičius ir Apeliacinių Rūmų jurisprudencijos tendencijas galima laikyti iškreiptomis dèl neteisèto valstybės suvereniteto pažeidimo, kai po valstybès okupacijos baudžiamosios bylos nutrauktos esą dèl „nesamos nusikalstamo darbo sudèties“46.

44 LCVA. Fondas 932, apyrašas 1 - Apeliaciniai rūmai. Baudžiamosios bylos 1934-1940.

45 Šios nusikalstamos veikos pagal jų pobūdị nedetalizuojamos dèl itin mažos reikšmès Apeliacinių Rūmų jurisprudencijai - dèl daugumos jų dar iki prasidedant teisminiam procesui buvo priimama Apeliacinių Rūmų prokuroro išvada dèl kaltinimo nutraukimo arba pakeitimo.

46 1940-06-17 Apeliacinių Rūmų prokuroro išvada kriminaliniam persekiojimui. LCVA f. 932, ap. 1, b. 321, 1. 2; 1940-06-23 Apeliacinių Rūmų prokuroro išvada kriminaliniam persekiojimui. LCVA f. 932, ap. 1, b. 322, 1. 4. ir kt. 
Tokia išvada perskaityta 14 asmenų.

Reikšmingiausi teismo darbo bruožai ir juos formavusios baudžiamųjų bylų aplinkybès aptartini remiantis anksčiau pateikta segmentacija.

Priklausymas slaptoms organizacijoms. 1934-1940 m. laikotarpiu teismas išnagrinėjo 158 baudžiamąsias bylas dèl asmenų veikimo slaptose, priešvalstybinę veiklą vykdžiusiose organizacijose. Tai kiekybiškai reikšmingiausia jurisprudencijos dalis, tad ne be pagrindo Teisingumo ministerijoje dar iki Apeliacinių Rūmu ịsteigimo spręsta dèl definicijos „slapta organizacija“: „slapta organizacija yra tik tuomet, jeigu ji dirba ką nors slapto, kuri susiorganizavo be sekimo organų žinios ${ }^{6447}$.

Lentelè Nr. 1. Duomenys apie tiriamąị baudžiamųjų bylų segmentą

\begin{tabular}{|c|c|c|c|c|}
\hline Teisès norma & $\begin{array}{l}\text { B. St. pap. ir } \\
\text { pak. } 6 \text { str. }\end{array}$ & $\begin{array}{l}\text { B. St. pap. ir } \\
\text { pak. } 7 \text { str. }\end{array}$ & TVSI 6 str. & TVSI 21 str. \\
\hline $\begin{array}{c}\text { Teisès } \\
\text { normos } \\
\text { esmė }\end{array}$ & $\begin{array}{l}\text { Priklausymas slap- } \\
\text { tai organizacijai, } \\
\text { kurios tikslas - } \\
\text { pasiekti vieną iš } \\
\text { B. St. pap. ir pak. } \\
1 \text { str. „siekinių“48 }\end{array}$ & $\begin{array}{l}\text { Kurstymas dètis } \\
\text { prie anksčiau } \\
\text { minimais } \\
\text { požymiais } \\
\text { apibūdintinų } \\
\text { organizacijų }\end{array}$ & $\begin{array}{c}\text { Lietuvos piliečio } \\
\text { priklausymas slaptai } \\
\text { užsienio organizacijai, } \\
\text { kurios veikla nesu- } \\
\text { derinama su Lietuvos } \\
\text { ar lietuvių tautos } \\
\text { interesu }\end{array}$ & $\begin{array}{l}\text { Priklausymas } \\
\text { valstybès } \\
\text { valdymo } \\
\text { valdžios oficialiai } \\
\text { uždraustoms ir } \\
\text { uždarytoms } \\
\text { organizacijoms }\end{array}$ \\
\hline Sankcija & $\begin{array}{l}\text { Iki } 8 \text { metų sunkiujų } \\
\text { darbų kalèjimo }\end{array}$ & $\begin{array}{c}\text { Iki } 4 \text { metų } \\
\text { sunkiujjų darbų } \\
\text { kalèjimo }\end{array}$ & $\begin{array}{c}\text { Paprastasis } \\
\text { kalèjimas }\end{array}$ & $\begin{array}{c}\text { Paprastasis } \\
\text { kalèjimas }\end{array}$ \\
\hline Bylų kiekis & 152 & 4 & 1 & 1 \\
\hline $\begin{array}{l}\text { Apkaltinamujjų } \\
\text { nuosprendžių }\end{array}$ & 84 & 0 & 1 & 1 \\
\hline $\begin{array}{c}\text { Kasaciniụ } \\
\text { skundų }\end{array}$ & 47 & 0 & 0 & 1 \\
\hline
\end{tabular}

Visos šio tipo baudžiamosios bylos grịstos saugumo struktūrų surinkta informacija, tačiau dèl Vyriausiojo Tribunolo nurodytos pareigos teismui šią informaciją pagrịsti kitais įrodymais ${ }^{49}$, pvz., draudžiamo turinio literatūra, teismo ekspertų pateiktomis išvadomis ir pan., posèdžių metu visada spręstas šių duomenų teisingumo klausimas. İdomu, kad Apeliaciniai Rūmai nepreziumuodavo šios informacijos kaip teisingos de facto. Štai, tirdamas baudžiamają bylą, kurioje Jonas Merchetovas, Stasys Skukauskas, Juozas Trauklys kaltinami B. St. 51 str.

47 [Be datos] Teisingumo ministerijos susirašinèjimas dẻl Baudžiamojo statuto pakeitimų. LCVA, f. 385 , ap. 1, b. $196,1.70$.

48 B. St. pap. ir pak. įstatymo 1 paragrafe numatomi tokie 6-ajme jo str. minimi ,siekiniai“:

a) atimti Lietuvai nepriklausomybę,

b) Lietuvos teritorijos daliai atplěšti,

c) sudaryti su kitomis valstybėmis ryšiams, kurie ịžeidžia Lietuvos suverenumą,

d) nuversti konstitucijos keliu ịvestai tvarkai ir valdžiai.

49 1937-01-05 Vyriausiojo Tribunolo Baudžiamujjų bylų skyriaus teisèjų kolegijos sprendimas Saros Šalmanaitès baudžiamojoje byloje. LCVA f. 932, ap. 1, b. 132, 1. 52. 
ir B. St. pak. ir pap. 6 str., teismas pažymėjo, kad: „< „..> žmonės, ne kartą bylose ir teisme su priesaika viešai duodamai parodymus, žinomai, meluoja bei iškraipo faktus, būdami įspèti skaudžia atsakomybe, tai ko galima tikètis iš apmoka-

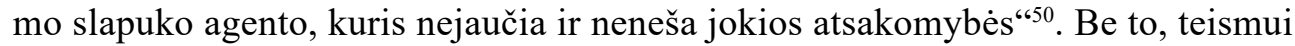
siekiant įrodyti teisiamujų kaltę, buvo būtina įrodyti, kad teisiamas asmuo veikè tyčia (B. St. 48 str.), asmuo, veikiantis slaptos priešvalstybinès organizacijos naudai, turejo pilnai suvokti savo veiksmus ${ }^{51}$. Būtent tai buvo sudètingiausia kaltès irodinèjimo našta, nes šios organizacijos „paprastai veikè ypač slaptai, griežtai ir konspiratyviai“"52. Visgi visi dẻl šių nusikaltimų baudžiamojon atsakomybẻn traukti asmenys buvo susiję su Lietuvos komunistų partija arba šios partijos organizacinėmis atšakomis, veikusiomis valstybès viduje ar užsienyje, o tai gerokai palengvindavo kaltès įrodinèjimo procesą.

Teismas didžiausią ịstatymų leistiną sankciją -8 metų sunkiųjų darbų kalèjimo bausmę - už šiuos nusikaltimus paskyrè 14 nuteistujų, metais trumpesnè sunkiụjų darbų kalèjimo bausmè skirta 5 asmenims, dar $29-6$ metų laisvès atėmimo bausmè. Dažniausiai (35 kartus) skirta 4 metų sunkiujų darbų kalèjimo bausmė. Svarbu paminèti, kad daugiausia šių bylų Apeliacinius Rūmus pasiekẻ 1936 m. 55, 1935 - 33, 1937 - 32 bylos. Mažiausiai - 1939 m. - 6, 1940 m. - 7 baudžiamosios bylos. Taigi intensyviausias bylų nagrinèjimo periodas negali būti siejamas su politiniais ar geopolitiniais procesais, pvz., Klaipèdos krašto praradimas (1938 m.) ar Lietuvos okupacija (1940 m.), t. y. ịvykiais, kuriuose istoriškai žinomas aktyvus uždraustų organizacijų elementų veikimas.

Disponavimas priešvalstybinio turinio literatūra. Apeliacinių Rūmų teisèjų kolegija iš viso išnagrinèjo 138 baudžiamąsias bylas dèl uždrausto turinio literatūros laikymo, platinimo ir gaminimo.

50 1936-12-12 Apeliacinių Rūmų sprendimas Jono Merchetovo, Stasio Skukausko, Juozo Trauklio baudžiamojoje byloje. $L C V A$ f. 932, ap. 1, b. 134, 1. 54 .

51 Supra note 70, 1. 66.

52 1936-11-18 12 Apeliacinių Rūmų sprendimas Fogelevičiaus Benjamino, Fišeraitès Civès baudžiamojoje byloje. LCVA. f. 932, ap. 1, b. 105a , 1. 110. 
Lentelè Nr. 2. Duomenys apie tiriamąji baudžiamųjų bylų segmentą

\begin{tabular}{|c|c|c|c|c|}
\hline Teisės norma & B. St. 132 str. & TVSI 18 str. & TVSI 17 str. & TVSI 19 str. \\
\hline $\begin{array}{l}\text { Teisès } \\
\text { normos } \\
\text { esmé }\end{array}$ & $\begin{array}{l}\text { Surašymas rašinio } \\
\text { arba padarymas } \\
\text { paveikslo, } \\
\text { nurodyto B. St. } 128 \\
\text { str. arba } 129 \text { str. }^{53} \text {, } \\
\text { norint juos išplatinti } \\
\text { arba viešai rodyti, jei } \\
\text { jie nebuvo išplatinti } \\
\text { arba viešai rodomi }\end{array}$ & $\begin{array}{c}\text { Platinimas ar } \\
\text { laikymas } \\
\text { uždrausto įvežti } \\
\text { iš užsienio spau- } \\
\text { dinio, kuris gali } \\
\text { kenkti Lietuvos } \\
\text { ar lietuvių tautos } \\
\text { interesui }\end{array}$ & $\begin{array}{c}\text { Leidyba } \\
\text { draudžiamo spau- } \\
\text { dinio arba leidinio, } \\
\text { kuris gali būti } \\
\text { laikomas valdžios } \\
\text { uždaryto ar su- } \\
\text { stabdyto periodinio } \\
\text { spaudinio tęsiniu }\end{array}$ & $\begin{array}{c}\text { Priešingo } \\
\text { Lietuvos ar } \\
\text { lietuvių tautos } \\
\text { interesui spau- } \\
\text { dinio, kuris } \\
\text { leidžiamas } \\
\text { subsidijuojant ji } \\
\text { užsienio lěšomis, } \\
\text { redaktorius ir } \\
\text { leidèjas }\end{array}$ \\
\hline Sankcija & $\begin{array}{c}\text { Iki } 3 \text { metų paprastojo } \\
\text { kalèjimo }\end{array}$ & $\begin{array}{c}\text { Paprastasis } \\
\text { kalèjimas }\end{array}$ & $\begin{array}{l}\text { Paprastasis } \\
\text { kalèjimas }\end{array}$ & $\begin{array}{c}\text { Bauda iki } 20 \\
\text { tūkst. litų arba } \\
\text { paprastasis } \\
\text { kalèjimas }\end{array}$ \\
\hline Bylų kiekis & 133 & 3 & 1 & 1 \\
\hline $\begin{array}{l}\text { Apkaltinamujju } \\
\text { nuosprendžių }\end{array}$ & 92 & 1 & 0 & 0 \\
\hline $\begin{array}{c}\text { Kasaciniụ } \\
\text { skundų }\end{array}$ & 38 & 1 & 0 & 0 \\
\hline
\end{tabular}

Šiose bylose draudžiamo turinio literatūros (rašinio, paveikslo, spaudinio ir pan.) formos varijuoja itin plačiu spektru - aptikta 24000 egzempliorių draudžiamų objektų: atsišaukimų, laikraščių, knygų, vèliavų, plakatų, rašinių, laiškų, nuotrau$\mathrm{kų,} \mathrm{atvirukų,} \mathrm{paveikslų} \mathrm{ir} \mathrm{kitų} \mathrm{to} \mathrm{meto} \mathrm{propagandinio} \mathrm{pobūdžio} \mathrm{objektų.} \mathrm{Didžiausias}$ draudžiamos literatūros kiekis (2 709 vnt.) užfiksuotas Kaune, aptikus komunistinès literatūros sandèlį ${ }^{54}$. Tačiau ịprastai buvo konfiskuojama 10-20 draudžiamo turinio literatūros egzempliorių. Šie objektai po teismo buvo perduodami Kaune veikusiam Valstybės saugumo policijos muziejui.

Tirdamas šias bylas, teismas privalëjo įrodyti objekto turinio kurstomaji pobūdị. Tiesa, ir šio tipo baudžiamosios bylos tiesiogiai ar netiesiogiai sietos su Lietuvos komunistų partija, kurios siekiai laikyti konstanta: „, $<>>$ ginkluotu sukilimu nuversti Lietuvoje esamoji valdžia ir valdymo tvarka ir joje igyvendinti Komunistų valdžia ir valdymo tvarka"55. Taigi teismui pakakdavo įrodyti priežastinị ryšș tarp

53 B. St. 128 str. numatomas ,pagrindiniais valstybès įstatymais nustatytą valdymą“ peikiantis objektas. B. St. 129 str. reglamentuojami aptariamieji objektai kursto:

„1) padaryti maišto arba išdavimo darbas;

2) nugriauti esamas valstybèje visuomenès sutvarkymas;

3) neklausyti arba priešdarbiauti įstatymui arba priverčiamajam įsakui arba teisètam valdžios įsakymui;

4) padaryti kuris kitas didysis nusikaltimas, be tų, kurie yra anksčiau paminèti.“

54 1936-10-15 Kratos protokolas. LCVA f. 932, ap. 1, b. 171, 1. 52.

55 1935-10-18 Apeliacinių Rūmų sprendimas Icikseno Orelio baudžiamojoje byloje. LCVA f. 932 , ap. 1, b. $38,1.35$. 
objekto turinio ir šių organizacijų tikslų ${ }^{56}$. Štai baudžiamojoje byloje, kurioje Stasys Jurginis ir Dovydas Rudelis Zeidinas kaltinti B. St. 132 str. ir B. St. pap. ir pak. 6 str., šio priežastinio ryšio įrodymui naudota ištrauka iš tuomet slapta leisto laikraščio „Tiesa“ (Nr. 3): „, ,..> proletarinè revoliucija ir sovietų valdžia tai - vienatiné išeitis iš dabartinio skurdo ir vargo. Už sovietinę valdžią Lietuvoje! “57 Apeliaciniai Rūmai priimtame sprendime konstatavo, kad: , , $\ldots>$ jos turinys yra aiškiai nusikalstamo pobūdžio, nes arba tiesiog kursto prie ginkluoto sukilimo, kad nuverstų esamos Lietuvoje visuomenès sutvarkymą bei valdžią ir jų vieton ịkurtų komunistinę, Rusijos pavyzdžiu, valdžią ir tvarką, arba nurodinèja, mokina, kaip prie to turi būti ruošiama visuomenè. ${ }^{\text {"58 }}$ Analogiška formulè naudota visose šio segmento bylose.

Tačiau pagrindinę ịrodinèjimo naštą sudarè pareiga ịrodyti kaltinamųų turinio žinojimo ir rastų objektų priklausymo jiems faktą. Kaltinamieji atkakliai įrodinėdavo, kad juos atnešęs nepažįstamas žmogus ar rasti gatvèje, o paimta ar ị gyvenamają vietą parsinešta, norejus tik patikrinti, kas ryšulyje, pakete, lagamine ar pan. Štai Gerberio Abraomo (kalt. B. St. 132 str. ir B. St. pap. ir pak. 6 str.) baudžiamojoje byloje pateiktas pasiteisinimas: „, ,..> atimtą čemodaną paèmiau panešti Kaune, Kęstučio gatveje, iš nepažịstamo žmogaus. Už tą darbą gauti du litai. Kas tame čemodane padèta, nežinia.“59 Tačiau įrodinėjimo procesą teisme „palengvindavo“ rèmimasis daiktiniais įrodymais ir saugumo struktūrų turima informacija. ${ }^{60}$

Sankcijos, kurias dažniausiai kaltinamiesiems skirdavo teismas, bylų duomenimis: 2 metų paprastojo kalèjimo bausmė (64 asmenys). Kitiems skirtos švelnesnès 1 metų laisvès atėmimo bausmès. Kitas ịdomus aspektas, kad dažniausiai pagal šiame straipsnyje reglamentuojamą nusikalstamą veiką nusikalsti buvo linkę žydų tautybès (72) ir lietuvių tautybès(55) asmenys.

Valstybès simboliụ ižeidimas ar niekinimas. Apeliaciniuose Rūmuose iš viso nagrinèta 18 baudžiamujų bylų dèl „gerbtinų ir brangintinų“ simbolių įžeidimo ar niekinimo. Tokiais simboliais teisme pripažinti „Vyties“ simbolis - dèl jo įžeidimo ar niekinimo iškeltos 8 baudžiamosios bylos, valstybinè vẻliava -5 , Vytauto Didžiojo vardu pavadintas ąžuolas - 2, Valstybinis himnas - 1, Antano Smetonos ir kunigaikščio Gedimino paveikslai - po 1 bylą.

\footnotetext{
56 Supra note 108.

57 1934-07-23 Kaltinamasis aktas Stasiui Jurginiui ir Dovydui Ruvinui Zeideliui. LCVA f. 932, ap. 1, b. $5,1.4$

58 1934-12-17 Apeliacinių Rūmų sprendimas Stasio Jurginio ir Dovydo Ruvino Zeidelio baudžiamojoje byloje. $L C V A$ f. 932 , ap. 1, b. 5, 1. 55.

59 1936-03-17 Kaltinamasis aktas Gerberiui Abraomui. LCVA f. 932, ap. 1, b. 63, 1. 4.

60 1936-06-22 Apeliacinių Rūmų sprendimas Gerberio Abraomo baudžiamojoje byloje. LCVA f. 932 , ap. 1, b. 63, 1. 42 .
} 
Lentelè Nr. 3. Duomenys apie tiriamąị baudžiamųjų bylų segmentą

\begin{tabular}{|c|c|}
\hline Teisès norma & TVSI 2 str. \\
\hline $\begin{array}{l}\text { Teisès normos } \\
\text { esmè }\end{array}$ & $\begin{array}{l}\text { İžeidimas ar niekinimas Lietuvos valstybės ženklo - Vyties, Lietuvos } \\
\text { tautinès, valstybinės ar karinès vėliavos arba kurio kito, brangintino ar } \\
\text { gerbtino dèl jo simbolinės reikšmės lietuvių tautai ar Lietuvai }\end{array}$ \\
\hline Sankcija & Paprastasis kalejjimas arba sunkiųjų darbų kalejjimas iki ketverių metų \\
\hline Bylų kiekis & 20 \\
\hline $\begin{array}{c}\text { Apkaltinamųjų } \\
\text { nuosprendžių }\end{array}$ & 15 \\
\hline Kasacinių skundų & 3 \\
\hline
\end{tabular}

Valstybinius ir tautinius atributus, turinčius simbolinę reikšmę, visais atvejais teismas pripažindavo a priori, o ,ižeidimo ir niekinimo“ veika vertinta skirtingai: žodiniu ịžeidimu, simbolio nuplèšimu, apspjaudymu, dainavimu, supjaustymu, išrovimu. İdomu, kad tarp šio pobūdžio nusikaltimus ịvykdžiusių asmenų dominuoja vokiečių tautinè mažuma - 14 nuteistujų. Jie nusikaltimus įvykdẻ Klaipėdos krašte, kuriame, atsižvelgiant ị politinę situaciją, vyravo antilietuviškos nuotaikos. Štai Grobštų k., Klaipėdos apskr., nacionalsiocialistinių pažiūrų grupės asmenų išpuolio metu vietos bendruomenès susirinkime apspjaudytas kunigaikščio Gedimino paveikslas ${ }^{61}$, Klaipedos krašto „išvadavimo“ proga Klaipėdos mieste 1936 m. sausio 15 dieną suplèšyta 13 Lietuvos tautinių vèliavų ${ }^{62}$, Pagègių apskr., Rukų k., smuklèje, vokiečių kalba sudainuotas Lietuvos himnas, ịterpiant necenzūrinius elementus $^{63}$, ir kt.

Visgi šiose baudžiamosiose bylose Apeliaciniai Rūmai buvo linkę skirti sąlyginai nedideles bausmes. Didžiausia skirta laisvès atėmimo bausmè - 1 metai paprastajame kalejime. Dažniau apsiribota piniginėmis baudomis ar lygtinėmis laisvès atėmimo bausmèmis. Tai liudija ir apie visuomenèje vyravusị nepakantumą išpuoliams prieš valstybès ar tautos simbolius.

Maišto ar kito valstybei pavojingo nerimo kèlimas. Dešimtyje baudžiamujų bylų ịrodinètas kaltinamujų „maišto“ kèlimas ar panašios formos visuomenès rimties trikdymas. „Maišto“ sąvoka čia nesietina su ginkluotu veikimu ar smurtiniais veiksmais ${ }^{64}$.

61 1935-11-29 Kaltinamasis aktas Pupšiui Mikui, Bočkui Antanui, Skomantui Benui, Gelžauskui Kajetonui, Tendžiui Jokūbui, Kybrancui Jonui, Klimaičiui Pranui, LCVA, f. 932, ap. 1, b. 85, 1. 4.

62 1936-05-29 Kaltinamasis aktas Siemoneit Heinz, Sprunk Heinz, Kibelkšties Bernard, LCVA f. 932 , ap. 1 , b. $81,1.4$.

63 1935-08-10 Kaltinamasis aktas Schepoks Franz, LCVA f. 932, ap. 1, b. 93, 1. 2.

64 Supra note 62. 
Lentelè Nr. 4. Duomenys apie tiriamąị baudžiamųjų bylų segmentą

\begin{tabular}{|c|c|}
\hline Teisės norma & TVSİ 14 str. \\
\hline Teisės normos esmė & Maišto ar kitokio valstybei pavojingo nerimo kèlimas \\
\hline Sankcija & Paprastasis kalèjimas arba sunkiüjų darbų kalèjimas \\
\hline Bylų kiekis & 10 \\
\hline Apkaltinamųjų nuosprendžių & 10 \\
\hline Kasacinių skundų & 8 \\
\hline
\end{tabular}

Definicijos, apibrezžiančios ,pavojingo nerimo“ sampratą, to meto teisès doktrina ir jurisprudencija nepateikia, o ,pavojingumo“ faktorių teismas identifikuodavo a priori. Tai daugiau oponavimas oficialioms valdžios struktūroms ir valstybės valdymo santvarkai: asmenų verbavimas stoti į Lietuvos komunistų partiją ${ }^{65}$, komunistinio turinio atsišaukimų platinimas ${ }^{66}$, ūkininkų streikų organizavimas ${ }^{67}$, vietos pareigūnų kurstymas neiti savo pareigų ${ }^{68}$.

Sankcijos dydžio už šias nusikalstamas veikas TVSI 14 str. iš esmès neapibrèžè. Dažniausiai 6 kartus skirta bausmè nesiekè 6 mėnesių laisvès atėmimo paprastajame kalejjime. Sunkiausia teismo skirta sankcija -6 metai sunkiujų darbų kalëjimo $^{69}$. Šiame bylų segmente taip pat derètų atkreipti dèmesị ị tautinių mažumų faktorių - dažniausiai nusikalsti buvo linkę žydų tautybės Lietuvos piliečiai - 5.

Valstybės ar lietuvių tautos įžeidimas ar niekinimas. Tai trečiasis pagal dydį baudžiamųjų bylų segmentas. Iš viso Apeliaciniai Rūmai nagrinejjo 101 tokio tipo bylą, kuriose priimtas sąlyginai didelis apkaltinamujų nuosprendžių skaičius -72 .

\footnotetext{
65 1938-05-25 Kaltinamasis aktas Vedegiui Broniui, LCVA f. 932, ap. 1, b. 199, 1. 5.

66 1939-10-24 Kaltinamasis aktas Keselmenui Chaimui LCVA f. 932, ap. 1, b. 294, 1. 7.

67 1937-05-11 Advokato Mykolo Šleževičiaus kasacijos skundas Vyriausiajam Tribunolui, LCVA f. 932 , ap. 1, b. $199,1.43$.

68 1937-01-26 Adv. Purènienès kasacijos skundas Vyriausiajam Tribunolui, LCVA, f. 932, ap. 1, b. $133,1.56$.

69 1939-10-09 Apeliacinių Rūmų sprendimas Strulaitès Chanos Itos baudžiamojoje byloje. LCVA f. 932 , ap. 1, b. $296,1.34$.
} 
Lentelè Nr. 5. Duomenys apie tiriamąị baudžiamųjų bylų segmentą

\begin{tabular}{|c|c|c|c|c|}
\hline Teisès norma & TVSİ 1 str. & TVSI 3 str. & TVSI 4 str. & TVSI 22 str. \\
\hline $\begin{array}{l}\text { Teisès normos } \\
\text { esmè }\end{array}$ & $\begin{array}{l}\text { Izžeidimas ar } \\
\text { niekinimas } \\
\text { lietuvių tautos } \\
\text { ar valstybès }\end{array}$ & $\begin{array}{l}\text { Slopinimas ar silp- } \\
\text { ninimas Lietuvos } \\
\text { piliečių valstybinės } \\
\text { ištikimybės, jų vals- } \\
\text { tybinio vieningumo } \\
\text { ar atsparumo arba } \\
\text { lietuvių tautinès } \\
\text { sąmonès }\end{array}$ & $\begin{array}{c}\text { Paramos prieš } \\
\text { Lietuvos valstybę } \\
\text { ieškojimas užsienyje } \\
\text { arba santykio su } \\
\text { užsienio subjek- } \\
\text { tais turéjimas, } \\
\text { laužantis valstybinès } \\
\text { ištikimybės pareigą }\end{array}$ & $\begin{array}{c}\text { Disponavimas } \\
\text { užsienio } \\
\text { valstybinių, } \\
\text { tautinių, } \\
\text { organizacinių } \\
\text { simbolių, jei tai gali } \\
\text { kenkti valstybès } \\
\text { interesui arba ịžeisti } \\
\text { tautinị jausmą }\end{array}$ \\
\hline Sankcija & $\begin{array}{c}\text { Paprastasis } \\
\text { kalejimas arba } \\
\text { sunkiujų darbų } \\
\text { kalèjimas } \\
\text { iki } 4 \text { metų }\end{array}$ & $\begin{array}{c}\text { Paprastasis } \\
\text { kalèjimas arba } \\
\text { sunkiujuu darbų } \\
\text { kalëjimas iki } 4 \text { metų }\end{array}$ & $\begin{array}{l}\text { Sunkiujų darbų } \\
\text { kalèjimas }\end{array}$ & $\begin{array}{c}\text { Bauda iki } \\
5 \text { tūkst. litų arba } \\
\text { areštas }\end{array}$ \\
\hline Bylų kiekis & 59 & 29 & 3 & 10 \\
\hline $\begin{array}{c}\text { Apkaltinamujjų } \\
\text { nuosprendžių }\end{array}$ & 42 & 20 & 3 & 7 \\
\hline $\begin{array}{c}\text { Kasacinių } \\
\text { skundų }\end{array}$ & 6 & 5 & 0 & 0 \\
\hline
\end{tabular}

Tai iš esmès abstrakčiomis ir lakoniškomis teisès normų nuostatomis grịstos baudžiamosios bylos, kuriose teismui tekdavo pareiga ịvertinti kaltinamujų vaidmenị , ižeidžiant ar niekinant Lietuvos valstybę ar lietuvių tautą“. Apeliaciniai Rūmai tokia veika traktavo necenzūrinius ar ižeidžiančius pasisakymus, minint Lietuvą, lietuvius ar valstybės vadovus, atskirų šalies regionų - Žemaitijos ar Klaipėdos krašto - gyventojus, ižeidžiančio turinio dainų dainavimą bei draudžiamų simbolių eksponavimą viešose vietose. Kontekstas, dèl kurio ịžeidinèta ar niekinta Lietuva ar lietuviai - itin plataus spektro. Lietuva žodžiu įžeidinèta dèl pilietinio karo Ispanijoje $^{70}$, augančios antisemitizmo idejų sklaidos Europoje ${ }^{71}$, Vokietijos agresijos prieš Lenkiją Antrojo pasaulinio karo pradžioje ${ }^{72}$, lietuvių kalbos vartojimo (atsisakymo išsiųsti laišką, ant kurio adresas užrašytas lietuvių kalba) ${ }^{73}$, lietuviškų atributų eksponavimo $^{74}$ ir net dèl nesèkmingo Stepono Dariaus ir Stasio Girèno skrydžio per Atlanto vandenyną ${ }^{75}$. Tačiau greta šiu kontraversiškai vertintinų aspektų vyravo ir realesnę grèsmę valstybès saugumui kèlę nusikaltimai, pvz., slaptas arklių iš Lietuvos ūkininkų supirkinèjimas ir jų perdavimas Tilžèje veikusiai Vokietijos kariuo-

\footnotetext{
70 1938-04-22 Liudininko kvotos protokolas. LCVA f. 932, ap. 1, b. 233, 1. 97.

71 1939-07-04 Kaltinamasis aktas Emiliui Laužiui. LCVA f. 932, ap. 1, b. 303, 1. 4.

72 1939-08-04 Liudininko kvotos protokolas. LCVA f. 932, ap. 1, b. 283, 1. 62.

73 1936-03-06 Liudininko kvotos protokolas. LCVA f. 932, ap. 1, b. 57, 1. 41.

74 1937-06-20 Kaltinamasis aktas Mitkui Viliui-Valerijui ir Volfhaueriui Alfredui-Maksui. LCVA f. 932, ap. 1, b. 233, 1.6 .

75 1935-01-15 Kvota. LCVA f. 932, ap. 1, b. 306, 1. 105.
} 
menei $^{76}$, šnipinėjimu ittariamų asmenų slèpimas nuo teisėsaugos ${ }^{77}$. Visgi dažniausiai šiuos nusikaltimus atlikti inspiruodavo politiniai įvykiai ar neigiama asmeninè patirtis, pvz., kerštas, girtumas ${ }^{78}$.

Idomu, kad šio tipo nusikalstamas veikas dažniausiai vykdẻ vokiečių tautybès asmenys - 56 kaltinamieji: 35 lietuvių, 5 žydų, 10 lenkų, 4 rusų kilmès asmenys. Sankcijos šio tipo nusikaltimus varijavo itin plačia amplitude - nuo smulkiu piniginių baudų iki laisvès atėmimo 4 metams sunkiụjų darbų kalëjime.

Priešingas valstybės ar lietuvių interesams veikimas. Pagal šias nusikalstamas veikas iškeltos 32 baudžiamosios bylos, priimta 16 apkaltinamụjų nuosprendžių. Tai daugiausia politinių, ideologinių motyvų pagrindu paremti nusikaltimai, atspindintys juos įvykdžiusių asmenų nuostatas, oponuojant valstybės valdymo valdžiai.

\section{Lentelè Nr. 6. Duomenys apie tiriamąji baudžiamųjų bylų segmentą}

\begin{tabular}{|c|c|c|c|c|c|c|}
\hline Teisès norma & TVSI 10 str. & TVSI 11 str. & TVSI 12 str. & $\begin{array}{l}\text { TVSI } \\
13 \text { str. }\end{array}$ & $\begin{array}{l}\text { TVSI } \\
15 \text { str. }\end{array}$ & $\begin{array}{l}\text { TVSI } \\
16 \text { str. }\end{array}$ \\
\hline $\begin{array}{c}\text { Teisès } \\
\text { normos } \\
\text { esmė }\end{array}$ & $\begin{array}{l}\text { Valdininko } \\
\text { ar tarnautojo } \\
\text { nevykdymas } \\
\text { valdžios } \\
\text { reikalavimų, } \\
\text { jei tai kenkia } \\
\text { valstybės } \\
\text { interesui }\end{array}$ & $\begin{array}{c}\text { Valdininko } \\
\text { ar tarnau- } \\
\text { tojo panau- } \\
\text { dota valdžia, } \\
\text { siekiant } \\
\text { paveikti } \\
\text { nusistatymą } \\
\text { arba valią } \\
\text { priešingai } \\
\text { valstybès ar } \\
\text { tautos } \\
\text { interesui }\end{array}$ & $\begin{array}{l}\text { Panaudojimas } \\
\text { ekonominio } \\
\text { santykio, } \\
\text { suteikimas } \\
\text { materialinès } \\
\text { naudos arba } \\
\text { pavartojimas } \\
\text { fizinès ar } \\
\text { psichinès prie- } \\
\text { vartos taip, kad } \\
\text { tai gali paveikti } \\
\text { nusistatymą arba } \\
\text { valią priešingai } \\
\text { valstybès ar } \\
\text { tautos interesui }\end{array}$ & $\begin{array}{c}\text { Prekybinès } \\
\text { ar koope- } \\
\text { racinės } \\
\text { ístaigos } \\
\text { igaliotinio } \\
\text { veikimas, } \\
\text { darant } \\
\text { politinę } \\
\text { ịtaką, } \\
\text { priešingą } \\
\text { valstybės } \\
\text { ar tautos } \\
\text { interesui }\end{array}$ & $\begin{array}{c}\text { Agitavi- } \\
\text { mas arba } \\
\text { propa- } \\
\text { gandos } \\
\text { varymas, } \\
\text { siekiant } \\
\text { kenkti } \\
\text { valstybės } \\
\text { ar tautos } \\
\text { interesui }\end{array}$ & $\begin{array}{l}\text { Skleidimas } \\
\text { pramany- } \\
\text { tos infor- } \\
\text { macijos } \\
\text { apie } \\
\text { valdžios } \\
\text { organų } \\
\text { arba } \\
\text { istaigos } \\
\text { veikimą, } \\
\text { jei tai } \\
\text { kenkia jų } \\
\text { autoritetui }\end{array}$ \\
\hline Sankcija & $\begin{array}{l}\text { Paprastasis } \\
\text { kalëjimas } \\
\text { arba } \\
\text { sunkiujuu } \\
\text { darbų } \\
\text { kalèjimas iki } \\
4 \text { metų } \\
\end{array}$ & $\begin{array}{c}\text { Paprastasis } \\
\text { kalèjimas }\end{array}$ & $\begin{array}{c}\text { Paprastasis } \\
\text { kalejjimas }\end{array}$ & $\begin{array}{l}\text { Paprastasis } \\
\text { kalëjimas } \\
\text { arba } \\
\text { sunkiųjų } \\
\text { darbų } \\
\text { kalèjimas } \\
\text { iki } 4 \text { metų } \\
\end{array}$ & $\begin{array}{c}\text { Papras- } \\
\text { tasis } \\
\text { kalè- } \\
\text { jimas }\end{array}$ & $\begin{array}{c}\text { Paprastasis } \\
\text { kalëjimas }\end{array}$ \\
\hline Bylų kiekis & 2 & 1 & 2 & 1 & 16 & 10 \\
\hline $\begin{array}{c}\text { Apkalti- } \\
\text { namujuu } \\
\text { nuosprendžių }\end{array}$ & 2 & 0 & 1 & 0 & 7 & 6 \\
\hline $\begin{array}{c}\text { Kasacinių } \\
\text { skundų }\end{array}$ & 1 & 0 & 0 & 0 & 0 & 2 \\
\hline
\end{tabular}

76 1939-01-05 Kaltinamasis aktas Leo Kuršatui. LCVA f. 932, ap. 1, b. 244, 1. 7.

77 1938-02-10 Apeliacinių Rūmų sprendimas Kristumo Majauro, Hermano Weisso, Makso Powilso ir Franco Stoltzo baudžiamojoje byloje. LCVA f. 932, ap. 1, b. 263, 1. 108.

78 1935-12-28 LR Apeliacinių Rūmų sprendimas Dovydo Suso budžiamojoje byloje. LCVA f. 932 , ap. 1, b. $72,1.62$. 
Ittariamieji baudžiamojon atsakomybèn traukti už nacionalsocialistinių ir socialistinių dainų dainavimą, propagandinių atsišaukimų ir leidinių platinimą, agitavimą nevesti vaikų i lietuviškas mokyklas, politinę agitaciją, viešą policijos pareigūnų įžeidimą, pramanytų žinių apie vyriausybę skleidimą, gandų apie Lenkijos teritorines ambicijas platinimą ir kt. İdomu, kad net trijose bylose pastebètinas gandu apie to meto vyriausybès vadovo Juozo Tubelio veiklą skleidimas. Štai kaltinamajji Juozą Jablonskị baudžiamojon atsakomybèn patraukti pakako dèl informacijos, kad jis Mosėdžio miestelio turgaus aikštejje išsakè gandus, kad: , , ..> Ministras Pirmininkas iš valstybės iždo prisivogè milijonus ir užsieny nusipirko kelis dvarus.“79

İdomu, kad dažniausiai baudžiamojon atsakomybèn traukti lietuvių tautybès asmenys - 22, taip pat 11 vokiečių ir 1 lenkų tautybès Lietuvos pilietis. Taigi tautinis motyvas nėra ryškus. Na, o reali laisvès atėmimo bausmė už šio pobūdžio nusikaltimus skirta vos dukart.

Kitos baudžiamosios bylos. Apeliaciniai Rūmai 1934-1940 m. laikotarpiu iš viso išnagrinèjo dar 29 baudžiamąsias bylas, iškeltas 12 skirtingų B. St. straipsnių pagrindu.

Kiekybiškai daugiausia baudžiamujų bylų (11) iškelta B. St. 129 str. pagrindu - tai viešas sakymas, skaitymas prakalbos ar rašinio arba disponavimas jais, kurstant grèsmę valstybei keliančius siekinius ${ }^{80}$. Tai - ívykdyti nusikaltimai, platinant draudžiamą literatūrą (plakatus ir atsišaukimus) ${ }^{81}$, iškeliant uždraustų organizacijų vèliavas ${ }^{82}$, deklamuojant komunistinio turinio eilèraščius ${ }^{83}$. Dėmesio verta baudžiamoji byla pagal B. St. 137 str. iškelta dèl neutralumo taisyklių pažeidimo, kai teisiamasis Stasys Černiauskas, veikdamas organizuotoje grupejje, 1939 m. Lietuvos teritorijoje rinko informaciją Lenkijos struktūroms apie Vokietijos kariuomenę. Už tai skirta 3 mėnesių paprastojo kalëjimo bausmè. ${ }^{84}$ B. St. 442 str. pagrindu iškeltos 2 baudžiamosios bylos dèl naudojimosi padirbtais dokumentais. Vienoje iš jų kaltu pripažintas ilgametis Lietuvos komunistų partijos vadovas Antanas Sniečkus $^{85}$. Likusios baudžiamosios bylos dèl priešiškai užsienio valstybei slapta suteiktos valstybès saugumui reikšmingos informacijos (B. St. 111), dèl veikimo ,sajungoje, žinomai uždraustoje“ (B. St. 124 str.), dèl veikimo „sajungoje“, deklaravusioje siekius kurstyti vykdyti įstatymu uždraustas veikas, kiršinti atskiras gyventojų grupes ar darbininkus (B. St. 125 str.), dẻl platinimo „mokslų arba nuomonių“, kuriomis skatinama maištauti, „nugriauti“ visuomenès santvarką, ,priešdarbiauti

\footnotetext{
79 1939-05-05 Kaltinamasis aktas Juozui Jablonskui, LCVA f. 932, ap. 1, b. 286, 1. 5.

80 Supra note 140.

81 1938-05-21 Kaltinamasis aktas Elijai Gertneriui. LCVA f. 932, ap. 1, b. 240, 1. 5.

82 1940-05-10 Kaltinamasis aktas Mockui-Mockevičiui Domui. LCVA f. 932, ap. 1, b. 274, 1. 3.

83 1940-02-03 Kaltinamasis aktas Inčiūrai Česlovui. LCVA f. 932, ap. 1, b. 292, 1. 4.

84 1940-04-24 Apeliacinių Rūmų sprendimas Janicki Andrzej, Černiausko Stasio, Auštro Juozo baudžiamojoje byloje. $L C V A$ f. 932 , ap. 1, b. 317, 1. 57.

85 1940-06-01 Apeliacinių Rūmų sprendimas Milvydo Antano, Antano Sniečkaus, Fristinšo Tindès, Petravičiaus Juozo baudžiamojoje byloje. LCVA f. 932, ap. 1, b. 329, 1. 57.
} 
ìstatymui“ (B. St. 130 str.), dèl vertimo tarnautojo neatlikti savo pareigos arba nusižengti ịstatymui (B. St. 145 str.), dẻl pabėgimo iš ịkalinimo vietos (B. St. 174 str.) ir dèl neteisèto disponavimo ginklu (B. St. 230 str.), nors ir buvo kvalifikuotos spręstinomis Apeliacinių Rūmų jurisdikcijoje, visgi teisiamuosiuose posėdžiuose nenagrinètos, neidentifikavus nusikaltimų sudèties.

\section{Išvados}

1. Apeliacinių Rūmų kompetencija pirmąja instancija nagrinèti baudžiamąsias bylas dèl grèsmių prieš valstybès saugumą, nustatyta Teismų santvarkos ịstatymo 19 str., turètų būti laikoma strategiškai reikšminga valstybès saugumo sistemai. Teismo jurisprudenciją sudaro 326 baudžiamosios bylos, iškeltos dèl politinių ir ideologinių aplinkybių inspiruotų nusikalstamų veikų. Asmenų, tarp kurių pastebètinas ir aktyvus tautinių mažumų subjektų veikimas, ịvykdžiusių šias nusikalstamas veikas, veikla vertintina kèlusi grèsmę valstybės ar selektyvių jos objektų saugumui, skatinusi neapykantą ar priešiškumą valstybès valdymo institucijoms. Iš 529 teismo pirmojoje instancijoje teistų asmenų apkaltinamieji nuosprendžiai priimti 245 subjektų atžvilgiu. Tai žymi teismo veiklos efektyvumą ir realų tuo metu traktuotų kaip grèsmę valstybės saugumui keliančių nusikaltimų užkardymą.

2. Apeliaciniuose Rūmuose nagrinètos baudžiamosios bylos traktuotinos inspiruotomis daugiausia ideologinių paskatų ar vidaus bei išorès politinių ịvykių. Teismo veikla, nagrinėjant baudžiamąsias bylas dẻl grèsmių valstybès saugumui, nors ir vertintina kaip strategiškai reikšminga, tačiau šių bylų nagrinėjimas teisiamuosiuose posėdžiuose laikytinas komplikuotu dèl atskiruose šių bylų segmentuose identifikuotinų aplinkybių.

3. Teismas, nagrinèdamas šio tipo baudžiamąsias bylas, rèmèsi recepuotojo Baudžiamojo statuto ir nacionalinès kilmès baudžiamujų įstatymų - Tautai ir Valstybei saugoti ịstatymo bei Baudžiamojo statuto papildymo ir pakeitimo įstatymo - nuostatomis. Vertinant pastaruosiuose teisès aktuose identifikuotinus fundamentalių žmogaus teisių pažeidimus kaip saviraiškos ir minties laisvès, teisès burtis ị organizacijas ir to meto politinio režimo preferencijų elementus, taip pat šiose teisès normose abstrakčiai ir nevienareikšmiškai suformuluotas nusikaltimų sudètis, jų pagrindu iškeltos baudžiamosios bylos definicijuotinos kaip politinès, tačiau atspindinčios realias grèsmes valstybès saugumui. 


\section{Literatūra}

1. Apanavičius, M., Dvareckas, S. Teismas ir teisingumas Lietuvos TSR. Vilnius: Mintis, 1984.

2. Apeliacinès instancijos ịkūrimas. Lietuvos apeliacinio teismo tinklalapis: $<$ http://www.apeliacinis.lt/lt/veikla/teismo-istorija/apeliacines-instancijosikurimas.html>

3. Baudžiamasis kodeksas. Laikinosios vyriausybės žinios. 1919, Nr. 2-3/26. Sud. Jablonskis, K. Baudžiamasis statutas, sud. Kaunas: 1930.

4. Baudžiamojo statuto papildymas ir pakeitimas. Laikinosios Vyriausybès žinios. 1920, Nr. 20-243.

5. [Be datos] Teisingumo ministerijos susirašinėjimas dèl Baudžiamojo statuto pakeitimų. LCVA, f. 385, ap. 1, b. 196.

6. [Be datos] Teisingumo ministerijos susirašinèjimas dèl Baudžiamojo kodekso. LCVA 385, ap. 2, b. 296. b. 790 .

7. [Be datos] Valstybei apsaugoti ịstatymo projektas. LCVA F. 923, ap. 1, Nr. 29.

8. Byla, J. Teismas nusik. darbų prieš Valstybès saugumą. Teisé, 1935,

9. Byla, J. Vyriausiojo Tribunolo 1924-1933 mety visuotiniu susirinkimy nutarimu rinkinys su Teisingumo ministerijos aplinkraščiais ir dalykine rodykle. Kaunas: Karvelio ir Rinkevičiaus Prekybos namų leidinys. 1934 m.

10. Dvareckas, S. Lietuvos teismai 1918-1940 m., Vilnius, 1997 m.

11. Ypatingi valstybès apsaugos ịstatai. Laikinosios Vyriausybès Žinios. 1919, Nr. 5/3. Nr. 6/62.

12. Karo teismo îstatai, Laikinosios Vyriausybès Žinios, Kaunas 1919,

13. Kavolis, M. Baudžiamojo proceso ìstatymas su komentarais. Kaunas: „Literatūros" knygynas. $1933 \mathrm{~m}$.

14. Laikinosios vyriausybès ịsakymai. Lietuvos aidas. 1918, 158 (206).

15. Laikinasis Lietuvos teismų ir jų darbo sutvarkymas. Laikinosios Vyriausybès žinios. 1919, Nr. 2-3/26.

16. LCVA. Fondas 932, apyrašas 1 - Apeliaciniai rūmai. Baudžiamosios bylos 1934-1940.

17. Lietuvos centrinis valstybės archyvas, Fondas 932, apyrašas Nr. 1, b. $1-329$.

18. Lietuvos centrinis valstybès archyvas, Fondas 932, apyrašas Nr. 2, b. 1-6.

19. Lietuvos Konstitucija. Vyriausybès žinios. 1938, Nr. 600-4199.

20. Lietuvos Valstybès Konstitucija. Vyriausybès žinios, 1928, Nr. 275/1778.

21. LTSR Liaudies komisarų tarybos 1940 m. rugsèjo 26 d. nutarimas Nr. 162 „Dèl Vyriausiojo Tribunolo ir Apeliacinių rūmų panaikinimo“. LTSR Aukščiausiosios tarybos žinios. 1940, Nr. 3-53. 
22. Maksimaitis, M. Iš Lietuvos teismų istorijos: Apeliaciniai Rūmai (1933-1944). Jurisprudencija. 2014, 21 (1).

23. Maksimaitis, M. Teismų santvarkos pagrindų formavimasis Lietuvoje (1918-1933). Jurisprudencija. 2013, 20 (2).

24. Maksimaitis, M. Rusijos teisès šaltiniai Lietuvoje 1918-1940 m. Jurisprudencija, 2012, Nr. 19(2).

25. Prof. Voldemaras nubaustas, o Karutis išteisintas. Diena. 1934, 45.

26. Römeris, M. Konstitucinès ir teismo teisés pasieniuose. Kaunas: Vytauto Didžiojo universiteto Teisių fakultetas, 1931.

27. Sagatienè, D. Sovietiniai bendrosios kompetencijos teismai Lietuvoje 1940-1941 ir 1944-1953 metais. Daktaro disertacija. Socialiniai mokslai, teisè. Vilnius: Mykolo Romerio universitetas, 2013.

28. Skipitis, R. Nepriklausoma Lietuva: atsiminimai. Čikaga: 1967.

29. Stoliarovas, A. Lietuvos Respublikos kariniai teismai 1919-1940 m. Daktaro disertacija. Kaunas: Vytauto Didžiojo universitetas, 2012.

30. Tautai ir valstybei saugoti istatymas. Vyriausybès žinios. 1934, Nr. 437-3044.

31. Teismų santvarkos įstatymas. Vyriausybès žinios. 1933, Nr. 419-2900.

32. Teismų santvarkos ịstatymo projektas. $L C V A$ f. 923, ap. 1, b. 784.

33. Teismų santvarkos įstatymas. Vyriausybès žinios. 1933, Nr. 419-2900.

34. Vilbikas, A. Teismai ir teisëjai Lietuvoje (1918-2008). Šiauliai, 2009. 


\title{
THREATS TO NATIONAL SECURITY \\ IN THE CHAMBER OF APPEAL
}

\author{
Tadas Valančius \\ PhD Candidate, Mykolas Romeris University
}

\section{Summary}

The aim of the research is to accomplish the analysis of the Chamber of Appeal as a court of first instance performance during the period of 1933-1940 and to reveal the examination peculiarities of criminal acts against national security of the case-law during the period by researching archival sources, legal documents and scientific literature.

The objectives of the research: to review the evolution, operational objectives and the ratio of the Chamber of Appeal in the judicial system of that time; to identify the legal framework that shaped the development of the Chamber of Appeal; to perform the analysis of criminal cases concerning threats to national security examined by the Chamber of Appeal and to highlight its features.

The research involves a statistical-quantitative analysis of criminal cases allowing a structured overview of the composition of jurisprudence and its essential features.

The results of the research lead to the conclusion that the Chamber of Appeal was the essential consequence and purpose of the judicial reform in 1933.

The court jurisprudence consists of 326 criminal cases with 529 convicted persons, including 245 prosecuted ones for criminal acts against state security implementation. Most criminal cases were brought for membership in organizations declaring anti-state aspirations and disposal of prohibited content literature. Criminal cases examined by the Chamber of Appeal are mainly considered as inspired by ideological incentives or internal and external political events. The defendants' guilt proof process was complicated, not allowing to form a consistent practice. This was caused by the conspiracy of criminal acts, political and ideological motives of people who performed crimes and differentiation of decisions evaluation in criminal cases.

Keywords: court, jurisprudence, national security, criminal cases investigation, interwar 


\section{AUTORIAUS LYDRAŠTIS}

Autoriaus vardas, pavardė: Tadas Valančius

Mokslo laipsnis ir vardas: doktorantas

Darbo vieta ir pareigos: Mykolo Romerio universiteto Teisès fakulteto Viešosios teisès institutas

Autoriaus mokslinių interesų sritys: teisės istorija, žmogaus teisės, konstitucinè teise

Telefonas ir el. pašto adresas: + 37060219 419;

valancius.tadas@gmail.com

\section{AUTHOR'S COVER LETTER}

Author' name and surname: Tadas Valancius Academic degree and name: $\mathrm{PhD}$ Candidate Workplace and position: Mykolas Romeris University Author's research interests: history of law, human rights, constitutional law Telephone and e-mail address: +37060219 419;

valancius.tadas@gmail.com 